\title{
Keramet: The Origin And Dissemination of Keramet (Miracles) of The Anatolian Sufis.
}

İlhan BAŞGÖZ*

Menakibnames, the written sources of the legendary life of the Prophet, and of Muslim saints (i.e evliya and enbiya), include some recurring miracles called mucize or miracles of the Prophet, and keramet, miracle of the saint, which can also be found in the oral discourse of the Anatolian Babas and Dedes.

In folklore studies such recurring small entities which can easily be identified and can not be further divided are called motifs. Such motifs can be found in folk tale, legend, anecdote, ballade, epic and so on.

Since the turn of the $19^{\text {th }}$ century folklorists tried to discover the historical and geographical origins and dissemination of folk tales by means of studying motifs. Religious studies, especially the study of contemporary religious history also find the keramet useful to detect the historical basis and the origin and diffusion of the related legend. This common objective of the two fields suggested to me, as a folklorist, that I should apply the finding of the folklore research in this area to religious studies.

Since 1930, scholars in the field of folklore, collected, categorized and indexed literally tens of thousands of motifs and published voluminous motif indexes.

The Motife Index of Folk Literature by Stith Thompson, a six volume work and Folk Traditions of the Arab World, a Guide to Motif Classification by Hasan el Shamy, are two important works in that field. Typen Turkishes Wolkmarchen, by Pertev Boratav and Wolfram Eberhard which deals only with the Turkish folk tales, should also be added to such motif studies.

I may say that almost all miracles of Muslim saints, with only a few exceptions can be identified in the international motif indexes and their motif numbers can be ascribed to these miracles. Here are some motif numbers of the folk narratives and those of the corresponding miracles.

B 551.3.

Crocodile carries man across river, or Ocean.

Sefer Dede crossed the ocean riding on the back of a crocodile.

* Prof. Dr. Indiana University 
(Evliya Çelebi, Yapı Kredi Yay. I: 188.)

B 557.5.1

Riding on the back of a lion (or deer).

Ahmet Rifai goes about on the back of a lion. (Hasluck, I: 289)

B.557. 5.1.0

Riding on the back of an ostrich,

Barak baba goes about riding on the back of an ostrich.(Köprülü, Influence: 16) This motif has no international motif number. I just added (0) to the previous motif number .

B 11.11

Fight with dragon or slayin dragon

Selim Han (Gölpınarlı, Vilayetname: 73), Hacım Sultan (Gölpınarlı, Vilayetname: 87), Ahi Evran (Gölpınarlı, Vilayetname: 121), and the Prophet Eliyah all kill dragon. (Hasluck, II: 430)

A.941.5.1

Spring breaks forth where saint smites rock

Hasan Demir Baba (Hasluck, II: 380) Hacım Sultan (Ocak: 214) and Hacı Bektaş (Gölpınarlı,Vilayetname: 55) touche the earth or stone and water breaks forth.

D.30

Animal transformed to man.

Kaygusuz Abdal touches a deer, the animal becomes a dervish. (Hasluck, I: 291)

\section{D.132}

Man transformed to animal.

Hacı Bektaş Veli transformes Ahi Evran to dragon. (Gölpınarlı, Vilayetname: 6)

D.141.

Transforming men to a dog.

Ahmet Yesevi transforms people to dog. (Köprülü, İlk Mutasavviflar: 46)

D452.1.4

Trnsformation of Stone to jewel.

Stone transformed to ruby when Mevlana touches it. (Gölpınarlı,Vilayetname: 60)

Uşak Üniversitesi Sosyal Bilimler Dergisi, 2013 Kış (6/1) 
D. 478 .

Water transformed to blood.

Hacı Bektaş pours water to his hand for ablution the water turns into blood. (Yazıc1, Ariflerin Menkabeleri: 540).

D 1508.1

A saint's breathe cures the sick and restores the speech of a person.

A disciple of Baba Ilyas and Othman Baba who the former restores the speech of a man and the latter cures the sick by breath.

D. 1820.

Magic sight of saint.

Ahmet Yesevi sees a bazergan from a long distance sinking in sea and saves him. (Köprülü, İlk Mutasavvıflar:38).

D. 47760.1 .2

Wine transformed to honey.

Wine in Mevlana's earten jug transformed to molasses. (Gölpınarl, Vilayetname: 95. Mollasses needs a new number which may be D4776.0.1.2.1)

E.63

Resuccitation by prayer

Hacı Baktaş Veli resuccitates a boy by hiding him under his dress. (Gölpınarlı, Vilayetname: 67)

D.11

Girl transformed to boy.

Hacı Bektaş caresses the head of girl who is transformed to boy. (Gölpınarlı, Vilayetname: 88)

D.2064

Making people sick

Hacı Bektaş Veli squeezes the hearth of a man and man looses (Gölpınarll, Vilayetname: 57)

The general name of Miraculous Healing by Saint, which includes several motifs is also found in some miracles..

V.221.

Healing by saint

Mevlana Celaleddin Rumi cures the broken leg of Seyit Ahmet. (Yazıcı, Ariflerin Menkıbeleri: 61).

Uşak Üniversitesi Sosyal Bilimler Dergisi, 2013 Kış (6/1) 
V.221.12

Curing blidness by saint

Kaygusuz Abdal restores the sight to one eye of the Egyptian Sultan. (Ocak: 206.)

V.228.5. 1

Saint walks upon water ( ocean )

Novices of Baba Ilyas walk, seat, and sleep upon sea

(Ocak: 217).

V.228.2

Saint immune to fire.

Huy Ata sits in hot fire, is not burned.(Gölpınarlı, Vilayetname: 44). A disciple of Baba Ilyas enters the fire but not burned. (Ocak: 117) Brazing fire turns to rose garden when Prophete İbrahim enters and seats there. (Knappert: 74)

\section{V.229.27}

Saint mystically appears and aids men in distress.

Hacı Bektaş saves sinking boat in the Black sea. (Gölpınarlı,Vilayetname: 70)

The identification of the keramet with the international motif numbers clearly indicates that they are all cross-cultural. In the keramet list there are one or two motifs which can not be found in the international motif indexes. Traveling on an ostrich is one of them, transforming water to molasses, pekmez is the other, although transformation of water to honey is listed in the motif indexes.

Since the international diffusion of keramet is so evident then how and with what methodological approach can we reach a tenable conclusion concerning the origin and the road of travel of keramet? Folklore scholars for almost a century have tried to answer that question using mainly, what is called the Historical Geographical method, or Comparative study or just the Finnish school approach. Their objective was to find the earliest, most complete and authentic form (urform) of a motif or folk narrative. They believe that the narrative emerged in a specific culture and geographical place at a historical time, and from there diffused to other cultures and areas. A researcher, for example would collect and compare hundreds of variants of a folk narrative from 200 cultures and based on them reaches a conclusion. The shortcoming of that approach is that some years later a new variant from a culture unknown to the researcher may surface and change 
the conclusion of that research. For that reason such comparative studies in folklore, today is disregarded to a great extend.

Keramets are small entities that are placed in a larger narrative written or oral such as a legend, an epic, a folk tale, etc. If they are studied isolated from the larger unit, the research will undoubtedly display the shortcoming of the comparative approach. Yaşar Ocak, for example, in a very carefull and pioneering study investigated the origine and dissemination of many keramets, which he rightly called motifs, in Bektaşi Vilayetnames. (Ocak) Although he expressed in two tables the Pre Islamic and the Biblical sources of Keramets, he did not limit his investigation to only these sources. He carefully searches almost all sources Budist, Menichean, Christiane, Sumerian and Hittite to find out the origine and dissemination of a keramet. For example, he concluded that the motif of slaying a dragon or fighting with a dragon originated either in the Middle East or Far East and disseminated from there. But all Medieval European epic heroes such as Siegfried, Dietrich von Bern, Arthur, Tristan, Lancelot, are also known as dragon slayers. (Röhrich) These new information that the researcher did not see might or might not change his conclusion. But an important source of information is left out from his study. This should not be a shortcoming of the researcher but a characteristic of the comparative study approach. Comparative studies in folklore for that reason shifts to some kind of social and psychological interpretation. Lutz Röhrich for example interprets the dragon slaying this way: "It is evident that dragons have something to do with human, especially with male anxiety. Dragons symbolize the struggle not only with external evil, but also with the evil in us, with the urge to power... Dragons are our problems, and our problems are dragons." (Röhrich: 205-209)

Instead of researching the motif isolated from the larger unit we may study the whole discourse written or oral as a basis of comparative study. If we study a menakipname or an epic or a folk romance as a written or recorded oral text, we will undoubtedly have new and rich data which would facilitate our investigation. I will give an example to that approach: One of the earliest sources of the legendary biography of prophets is called Kisas -el Enbiya, which was completed 1310 by Rabghuzi . The book defines all prophets by an extended formulaic epithet. For example, the epithet of the Prophet Adam is the following:

"He is the one who was created from earth who ascended to high heaven, who entered Paradise, who descended to the dark earth, who wept for three hundred years, who donned the robe of honor Adam the pure."

Uşak Üniversitesi Sosyal Bilimler Dergisi, 2013 Kış (6/1) 
“Ol topraktan yaratgan, kudret birle törütgen, adiz gökge aggan, uçmak içre girgen, yaruk uçmakdan ayrılgan, karangu dunyaya ingen. the Prophet Adam."(Rabghuzi, Vol 1: 12)

That kind of portrayal of a hero with an extended formulaic epithet is an important characteristic of Dede Korkut epic. All Oguz heroes in that epic which was written down in Anatolia in the second half of the $15^{\text {th }}$ century are associated with an extended epithet.

Here is Kara Budak's epithet: "He who smashed the fortress of Diyarbakır and Mardin, he who came and won Kazan Khan's daughter by his valour, he who despite his youth, the white bearded Oguz elders praise whenever they saw him, he who wore red silk trousers, and whose horse was born of the sea, Kara Budak, son of Kara Gune. (Hemidilin Merdin kalasın tepip alan, demir yaylı Kipçak Melike kan kusturan, Oguzun ak sakallı kocaları görende ol yigidi tahsinleyen, al mahmuzi şalvarlı, atı bahri hotazlı, Kara Güne oglu Kara Budak.)"(Gökyay: 73)

Here the epithet of Bamsi Beyrek "He who flashed forth from the Bayburt fortress, he who came across to his own many colored bridal tent, who is the hope of seven maidens, the darling of teeming oguz, the minister of Prince Kazan, Bamsı Beyrek who owns the Grey Horse. (Parasarın Bayburt kalesinden parlayıp uçan, ap-alaca gerdeğine karşı gelen, Oguz imreencesi, Kazan Hanın ınagı, boz aygırlı Bamsı Beyrek.)" (Gökyay: 73)

This epithete -hero association is found only in Turkic epic and no other epics of the world include such formulaic description of the hero.

What is interesting in that hero- epithet relationship in the heroic epic and Kisas el Enbiya is that the subject of both is the summary of the legendary life story of the epic heroes and Prophets. And furthermore, in both formulaic epithets we find the same narrative style, which may be called rhythmical prose. It includes internal rhythms, parallelism, alliteration and repeated number of syllable in each part of the symmetric division. . The author of the Kisas el Enbiya, for example, praises the ruler of the period in Easter Turkestan: "Our prince is a most glorious leader, crown of the rulers, patron of the religious scholars, of princely blood, purest of young men, with a glorious name, of blessed character, and virtuous name, whorty of Islam, of Mongol stock but of Muslim faith, reliance of men, pride of the faithfull, with lofthy aspiration and sharp intelligence, namely Nasireddin Tokbuga." ( Rabghuzi, Vol. 2: 6)

"Begimiz tacel umerea muhibbil ulema, beyler urug1, yigitler arıg1, kutlug datlig, yahşi kiliglig, İslam yaraglig, Mogul soylug, Muslüman dinlig, ademiler inançi, müminler kıvançı, himmeti böyük, aklı yetig, Nasireddin 
Tog Buga." (Rabghuzi, vol.1: 5) Dede Korkut Epic displays the same narrative style. Here is the the praise of Kazan Khan: "Son of Ulaş, chich of the long-plumed bird, hope of the wretched and the helpless, lion of the Emet river, tiger of the Karajuk, master of the chesnut horse, father of Khan Uruz, son-in-law of bayindir khan, luck of the teeming Oguz, prop of forsaken warior Salur Kazan Khan."

"Erenlerin aslanı, tüli kuşun yavrusu, Amid suyunun aslanı, Karaçuğun kaplanı, konur atın iyesi, Han Uruzun babası, Bayındır hanin güvegisi, kalın Oguzun devleti, kalmiş yiğit arkası, Salur Kazan."(Gökyay: 16)

We can continue our comparison by examining another theme in the menakipname and Dede Korkut Epic. In the Vilayetname, the Menakip of Hacı Bektaş Veli, Hacı Bektaş flew to Sulucakarahöyük in the form of a pigeon and landed on a rock. The saints of Rum sent Hacı Dogrul in the form of a falcon who attacks Hacı Bektaş Veli. The fight between the two which ended with the defeat of Hac Dogrul seems to be the repeatition of the fight between Deli Dumrul and Azrail, the angel of death in Dede Korkut epic. (Boratav, vestiges) Even the name of Dogrul and Dumrul which are just different pronunciations of the epic name, left no doubt that the Vilayetname of Hacı Bektaş was heavily impacted by the epic. In conclusion, it may be said that the epic discourse which preceded the other kind of narratives in Anatolia, including the books of menakib strongly influenced the narratives, written and oral.

\section{References}

Boratav, P. N. (1960). Vestiges oghouz dans la tradition bektaşi. Acten des

XXIV. International des sciences anthropologiques et ethnologiques, tome II, Paris: 141-148.

Eberhard, W. - Boratav, P. N. (1953). Typen Türkischer Volkmarchen.

Wiesbaden.

Evliya Çelebi Seyahatnamesi.(2006). İstanbul: Topkapı Sarayı Kütüphanesi yazmas1.

Gökyay, O. Ş. (1973). Dedem Korkudun Kitabı. İstanbul: Millî Eğitim Bakanlığı Yayını.

Gölpınarlı, A. (1958) Vilayetname, Menakib-1 Hacı Bektaş-1 Veli. Inkilap

Kitabevi, Istanbul.

Hasan M. El-Shamy. (1995). Folk Traditions of the Arab World. - A Guide to 
Motif Classification- II vols. Indiana University Press. BloomingtonIndianapolis.

Hasluck, F.W. (1956) Christianity and Islam Under the Sultans. II volumes.

New York: Octagons Books.

Knappert, J. (1985). Islamic Legends, 2 vols. Leiden, E.J.Brill

Köprülü, M. F. (1929). lnfluence du chamanisme turco-mongol sur les ordres mystiques musulmanes. Istanbul. Zellitch Freres.

Ocak, A. Y.(1983) Bektaşi Menakibnamelerinde İslam Öncesi İnanç Motifleri. Istanbul: Enderun.

Rabghūzī, al. The Stories of the Prophets Qișas al-Anbiyā' . An Eastern Turkish

Version. two vols. The text and English translation. Critically edited by H.E.Boeschoten, M. Vandamme and S. Tezcan with the assistance of $\mathrm{H}$. Braam and B. Radtke.. E.J. Brill, Leiden, New York, Köln 1995. English translation by J. O'Kane and M. Vandamme.

Rohrich, L. (1980). Problems of Dragon Lore. in Folklore on Two Continents.

Essays in honor of Linda Degh.ed.,by.Nikolai Burlakoff, Carl Lindahl .Trickster Press. Bloomington, Indiana.

Thompson, S. (1955-58). Motif Index of Folk Literature. VI cilt.

Bloomington, Indiana University Press.

Yazıcı, T. (1973). Ariflerin Menkıbeleri. Menakıb al-Arifin by Ahmet Eflaki.

Istanbul: Hürriyet Yayınları,

I intended to argue that in two cultures which are closely associated with history and geography the oldest may be the origine of the new one. It seemed to me logical that the historically ancient motif or narration might be the origine of the following ones. My dear friend Hasan el Shamy cautioned me that this conclusion may not be tenable. Because in the Ancient tale of the Middled east, recorded in the period of Ramses II, $6^{\text {th }}$ century B.C. some motives which I considered early Muslim motives, are found. These rae Motif no. D1610.18.1.1 Sphink Speaks.

E 721.1.0.1 The dead comes to communicate with the living in dream.

V510.1.1 Image of deity speaks in vision to devotee.

V510. 3.1 Sacred person (prophet, saint) speaks in vision to mortal. Masperoel Shamy Ancient Egypt tales. 229-32. Types of the .. Folktale s. 426. 